\title{
Family-Centered Care: Current Applications and Future Directions in Pediatric Health Care
}

\author{
Dennis Z. Kuo • Amy J. Houtrow • Polly Arango • \\ Karen A. Kuhlthau · Jeffrey M. Simmons • \\ John M. Neff
}

Published online: 12 February 2011

(C) The Author(s) 2011. This article is published with open access at Springerlink.com

\begin{abstract}
Family-centered care (FCC) is a partnership approach to health care decision-making between the family and health care provider. FCC is considered the standard of pediatric health care by many clinical practices, hospitals, and health care groups. Despite widespread endorsement, FCC continues to be insufficiently implemented into clinical practice. In this paper we enumerate the core principles of FCC in pediatric health care, describe recent advances applying FCC principles to clinical practice, and propose an agenda for practitioners, hospitals, and health care groups to translate FCC into improved health outcomes, health care delivery, and health care system transformation.
\end{abstract}

Keywords Family-centered care $\cdot$ Family-centered rounds · Patient-centered care

Polly Arango passed away in June 2010. This manuscript is dedicated to her for her lifetime work on behalf of families and children.

\section{Z. Kuo}

Center for Applied Research and Evaluation, Department of Pediatrics, University of Arkansas for Medical Sciences, Little Rock, AR, USA

D. Z. Kuo $(\bowtie)$

Arkansas Children's Hospital, Pediatrics/CARE Slot 512-26,

1 Children's Way, Little Rock, AR 72202, USA

e-mail: dzkuo@uams.edu

\author{
A. J. Houtrow \\ Department of Pediatrics, University of California at \\ San Francisco, San Francisco, CA, USA \\ P. Arango \\ Family Voices, Algodones, NM, USA \\ K. A. Kuhlthau \\ Center for Child and Adolescent Health Policy, MassGeneral \\ Hospital for Children, Boston, MA, USA
}

\author{
Abbreviations \\ FCC Family-centered care \\ PCC Patient-centered care \\ FCR Family-centered rounds \\ CSHCN Children with special health care needs \\ MCHB Maternal and Child Health Bureau \\ AAP American Academy of Pediatrics \\ IPFCC Institute for Patient- and Family-Centered Care
}

\section{Introduction}

Family-centered care (FCC) has been described as a partnership approach to health care decision-making. As a philosophy of care, FCC, and the related term patient-

\author{
K. A. Kuhlthau \\ Department of Pediatrics, Harvard Medical School, Boston, MA, \\ USA \\ J. M. Simmons \\ Cincinnati Children's Hospital Medical Center, Cincinnati, OH, \\ USA \\ J. M. Neff \\ Seattle Children's Hospital, Seattle, WA, USA \\ J. M. Neff \\ Department of Pediatrics, University of Washington School of \\ Medicine, Seattle, WA, USA
}


centered care (PCC), have been recognized by multiple medical societies, health care systems, state and federal legislative bodies, the Institute of Medicine, and Healthy People 2020 as integral to patient health, satisfaction, and health care quality [1-4].

FCC, however, is at a crossroads today. Fundamental misunderstandings persist about what FCC is, how to implement FCC, and how to determine the family-centeredness of care. FCC cannot deliver on its promises unless greater understanding and support for FCC are achieved by health care providers. More than anything else, FCC is an attitude change in the way clinical care is delivered [5], as families-as-partners fundamentally challenge the care paradigm of unilateral responsibility for decision-making.

This commentary on the state of FCC in child health draws on the diverse clinical, research, and advocacy experience of the authors. We highlight advances in FCC practices in child health and suggest ways to advance the state of FCC in pediatric health care.

\section{What Is Family-Centered Care?}

Family-centered care can be illustrated with the following case:

Adam, age 5, was referred for a tracheostomy due to chronic lung disease, vocal cord paralysis, and recurrent aspiration. After Adam underwent surgery, the tracheostomy tube dislodged 3 times during the first night post-op. After the third dislodging, the tube was sutured in place at the bedside. The suturing caused Adam considerable pain. When the tube dislodged yet again, the surgeon and the parents had a team meeting to discuss possible options. The father suggested to the surgeon that he would hold the tube in place himself and keep Adam calm. After some discussion, the surgeon agreed to place the tracheostomy again. Adam's father held the tube in place for $72 \mathrm{~h}$, and the tracheostomy tube successfully held.

Family-centered care is commonly used to describe optimal health care as experienced by families. The term is frequently accompanied by terms such as "partnership," "collaboration," and families as "experts" to describe the process of care delivery [2, 6-8]. The true story of Adam and his family (all names in this manuscript are changed) demonstrates FCC at its best, with information sharing, partnering, respect, and negotiation leading to a successful outcome in a difficult clinical scenario. By itself, though, the term FCC is non-specific and lends itself to wide interpretation for implementation and measurement. Is
FCC simply asking families what they want to do? Is it about family satisfaction, or quality health care? Ironically, such misunderstandings about appropriate processes of care can drive families and providers further apart $[9,10]$.

A consensus definition of FCC practices and actions has not been achieved to date [7, 11]. However, considerable agreement has been achieved on FCC principles, developed by groups such as Family Voices, the Maternal and Child Health Bureau (MCHB), the American Academy of Pediatrics (AAP), and the Institute for Patient- and FamilyCentered Care [2, 12, 13]. Table 1 lists the principles developed by these groups. The following general principles are shared:

- Information Sharing: The exchange of information is open, objective, and unbiased.

- Respect and Honoring Differences: The working relationship is marked by respect for diversity, cultural and linguistic traditions, and care preferences.

- Partnership and Collaboration: Medically appropriate decisions that best fit the needs, strengths, values, and abilities of all involved are made together by involved parties, including families at the level they choose.

- Negotiation: The desired outcomes of medical care plans are flexible and not necessarily absolute.

- Care in Context of Family and Community: Direct medical care and decision-making reflect the child within the context of his/her family, home, school, daily activities, and quality of life within the community.

FCC principles are frequently aligned with a vision of effective health care delivery. The AAP regards FCC as an integral component of the medical home [14], and the MCHB regards FCC as a core objective for care of children with special health care needs (CSHCN) within state Title V programs and Healthy People 2020 Objectives [15]. Ideally, the principles drive our understanding of essential FCC practices, but this is not always so, as we will discuss further.

A related term "patient-centered care" is frequently used interchangeably with FCC. The Institute of Medicine recognizes patient-centered care as one of the 6 central aims for high quality health care, and in 2007, the PatientCentered Medical Home was affirmed by multiple groups as the standard of health delivery [16]. Epstein and colleagues have articulated the importance of patient-centered care, described as "the quality of interactions between patients and clinicians," to national health care policy and reform [17]. However, we believe FCC is the term of choice as it relates to pediatric care, when families are most involved with their children. FCC moves beyond patientclinician interaction by considering the needs of all family members, not just the child [18]. 
Table 1 Comparison of principles of family-centered care

\begin{tabular}{|c|c|c|c|c|c|}
\hline $\begin{array}{l}\text { Categories of } \\
\text { principles }\end{array}$ & MCHB [12] & $\begin{array}{l}\text { Institute for Patient- and } \\
\text { Family-Centered Care } \\
\text { (IPFCC) [13] }\end{array}$ & $\begin{array}{l}\text { AAP [2] and IPFCC Joint } \\
\text { statement }\end{array}$ & $\begin{array}{l}\text { Cronin/Shaller } \\
{[90]}\end{array}$ & Common principles \\
\hline $\begin{array}{l}\text { Information } \\
\text { sharing }\end{array}$ & $\begin{array}{l}\text { Open and objective } \\
\text { communication and } \\
\text { information sharing }\end{array}$ & $\begin{array}{l}\text { Information sharing: } \\
\text { complete and unbiased } \\
\text { information sharing that } \\
\text { is "affirming and useful" }\end{array}$ & $\begin{array}{l}\text { Sharing honest and } \\
\text { unbiased information in } \\
\text { ways "useful and } \\
\text { affirming" }\end{array}$ & $\begin{array}{l}\text { Free flow and } \\
\text { accessibility } \\
\text { of } \\
\text { information }\end{array}$ & $\begin{array}{l}\text { Open and objective } \\
\text { information sharing } \\
\text { between families } \\
\text { and providers }\end{array}$ \\
\hline $\begin{array}{l}\text { Respect and } \\
\text { honoring } \\
\text { differences }\end{array}$ & $\begin{array}{l}\text { All respect the skills and } \\
\text { expertise brought to } \\
\text { relationship } \\
\text { Honors cultural diversity } \\
\text { and family traditions }\end{array}$ & $\begin{array}{l}\text { Dignity and respect: honor } \\
\text { patient and family } \\
\text { perspectives and choices, } \\
\text { including knowledge, } \\
\text { values, beliefs, and } \\
\text { cultural backgrounds }\end{array}$ & $\begin{array}{l}\text { Respecting each child and } \\
\text { his or her family } \\
\text { Honoring racial, ethnic, } \\
\text { cultural, and } \\
\text { socioeconomic diversity, } \\
\text { and its effect on families } \\
\text { experience and perception } \\
\text { of care } \\
\text { Recognizing and building } \\
\text { on strengths of child and } \\
\text { family }\end{array}$ & $\begin{array}{l}\text { Respect for } \\
\text { patient needs } \\
\text { and } \\
\text { preferences } \\
\text { Sensitivity to } \\
\text { nonmedical } \\
\text { and spiritual } \\
\text { dimensions }\end{array}$ & $\begin{array}{l}\text { Mutual respect for } \\
\text { family preferences, } \\
\text { skills, and expertise } \\
\text { Sensitivity to cultural } \\
\text { and spiritual } \\
\text { dimensions }\end{array}$ \\
\hline $\begin{array}{l}\text { Partnership } \\
\text { and } \\
\text { collaboration }\end{array}$ & $\begin{array}{l}\text { Families and professionals } \\
\text { work together in best } \\
\text { interests of child and } \\
\text { family, with child } \\
\text { assuming a partnership } \\
\text { role as s/he grows; there is } \\
\text { an individual and } \\
\text { developmental approach } \\
\text { Partnership between } \\
\text { families and professional } \\
\text { is the foundation of FCC }\end{array}$ & $\begin{array}{l}\text { Participation: patients and } \\
\text { families encouraged and } \\
\text { supported in participating } \\
\text { in care and decision } \\
\text { making at the level they } \\
\text { choose }\end{array}$ & $\begin{array}{l}\text { Collaborating with families } \\
\text { at all levels of health care, } \\
\text { in the care of child, } \\
\text { professional education, } \\
\text { policy making, and } \\
\text { program development } \\
\text { Support and facilitate } \\
\text { choice about approaches } \\
\text { to care and support } \\
\text { Providing/ensuring formal } \\
\text { and informal support for } \\
\text { patient and family at all } \\
\text { ages }\end{array}$ & $\begin{array}{l}\text { Collaboration } \\
\text { and team } \\
\text { management } \\
\text { Education/ } \\
\text { shared } \\
\text { knowledge }\end{array}$ & $\begin{array}{l}\text { Partnership and } \\
\text { collaboration in } \\
\text { decision making, } \\
\text { meeting the the } \\
\text { needs, strengths, } \\
\text { values, and abilities } \\
\text { of all } \\
\text { Decisions are made } \\
\text { including families } \\
\text { at the level they } \\
\text { choose }\end{array}$ \\
\hline Negotiation & $\begin{array}{l}\text { Participants make decisions } \\
\text { together } \\
\text { There is a willingness to } \\
\text { negotiate } \\
\text { Trust is acknowledged as } \\
\text { fundamental }\end{array}$ & & $\begin{array}{l}\text { Empowering families to } \\
\text { discover their own } \\
\text { strengths, build } \\
\text { confidence, and make } \\
\text { choices and decisions } \\
\text { about their health }\end{array}$ & $\begin{array}{l}\text { Involvement } \\
\text { of family } \\
\text { and friends }\end{array}$ & $\begin{array}{l}\text { Partnership and } \\
\text { collaboration } \\
\text { between team } \\
\text { members }\end{array}$ \\
\hline $\begin{array}{l}\text { Care in } \\
\text { context of } \\
\text { family and } \\
\text { community }\end{array}$ & $\begin{array}{l}\text { Develops policies, } \\
\text { practices, and systems that } \\
\text { are family-friendly/ } \\
\text { centered in all settings } \\
\text { Recognizes importance of } \\
\text { community-based services }\end{array}$ & $\begin{array}{l}\text { Collaboration: patients and } \\
\text { families included on an } \\
\text { institution-wide basis on } \\
\text { program development, } \\
\text { implementation and } \\
\text { evaluation, facility } \\
\text { design, and professional } \\
\text { education }\end{array}$ & $\begin{array}{l}\text { Flexibility in organization } \\
\text { policies, procedures, and } \\
\text { practices so services can } \\
\text { be tailored to needs, } \\
\text { beliefs, and cultural } \\
\text { values of child and family }\end{array}$ & & $\begin{array}{l}\text { Incorporation of } \\
\text { families at all levels } \\
\text { of care, including } \\
\text { encounter, } \\
\text { institution, and } \\
\text { policy settings }\end{array}$ \\
\hline
\end{tabular}

\section{How Did We Get Here? A History of Family-Centered Care}

Understanding FCC today requires a review of historical developments. The first hospital to care exclusively for children was the L'Hopital Des Enfants-Malades in Paris in 1802 [19] and, in the United States, the Children's Hospital of Philadelphia in 1855. Families in the hospital setting were relegated to a visitor or attendant role [11]. In parallel, families of children with intellectual impairments were encouraged to institutionalize their children at facilities such as the Experimental School for Teaching and Training Idiotic Children in Massachusetts [20].

Midway through the twentieth century, with the increased recognition of child/family separation trauma in the inpatient setting, hospital policies were altered to allow for rooming-in, open visiting hours, sibling visits, and accompanying children to surgeries [11]. Hospital inpatient rounds, which had moved away from the bedside and to the conference room [21], began to move back towards the 
bedside [22]. Family advocates played a large role in changing hospital-based care for children and their families, just as they were central to the process of promoting the deinstitutionalization of children with intellectual and other disabilities in their communities [23]. Family advocates were essential to the passage of the first special education law (P.L. 94-142) in 1975, the Early Intervention "Part C" several years later, and the first Katie Beckett Home and Community-Based Medicaid Waiver in 1982 that enabled many children and adults with disabilities and chronic conditions to be cared for at home.

Family advocacy for children with special needs subsequently extended into the health care policy arena. With the backing of family advocates, the MCHB and the US Surgeon General sponsored several national conferences on children with special health care needs in the mid-1980s [24]. Pediatricians, researchers, and policymakers heard from families who spoke about what it took to care for their children at home; the importance of partnerships, trust, and respect with their children's health professionals; and the benefits of joint decision-making. In 1987 the Surgeon General called for "coordinated, family-centered, community-based care for children with special health care needs and their families" [25]. In 1989 the MCHB changed its mission to read: "Provide and promote family-centered, community-based, coordinated care for children with special health care needs and to facilitate the development of community-based systems of services for such children and their families" [15].

Starting in the 1990s, the MCHB supported medical home learning collaboratives and the national grassroots family network, Family Voices, leading to family-to-family health information centers in every state. In 2001, the Institute of Medicine named PCC as crucial for health care quality [1], and by 2003, the AAP had incorporated FCC into multiple policy statements and affirmed FCC as the standard of health care for all children [2]. FCC and PCC appear in Healthy People 2020 as key outcomes of CSHCN receiving care in a "family-centered, comprehensive, coordinated system" [4], and the Patient Protection and Affordable Care Act calls for the establishment of a Patient-Centered Outcomes Research Institute [26].

\section{Where Are We Now? Applications of Family-Centered Care}

The presence of FCC at the highest policy level underscores the rising attention that FCC is receiving in clinical settings. Implementation, advocacy, and policy of FCC can be grouped into two settings: inpatient, exemplified by family-centered rounds (FCR), and ambulatory, exemplified by the Medical Home concept. The Medical Home concept is, in turn, intertwined historically with the system of care for CSHCN [27]. With different origins, operationalizing FCC in different settings has not always resulted in similar applications and outcomes within the inpatient and ambulatory settings.

\section{The Inpatient Setting}

Family-centered rounds (FCR) [28] are described as "interdisciplinary work rounds at the bedside in which patient and family share in the control of the management plan" [29]. In 2003, the AAP recommended that "conducting attending physician rounds (i.e., patient presentations and rounds discussions) in the patients' rooms with the family present should be standard practice" [2]. Family presence alone is considered insufficient, as family members must participate in the discussion and decision-making; at its best, the presence and participation of families promotes the FCC principles of Information Sharing, Partnership and Collaboration, and Negotiation. Specifics about roles and responsibilities of families can be unclear, however [18], which may tie directly into how well FCR addresses the principles of Respect/Honoring Differences and Care in the Context of Family and Community. Families have expressed a strong preference for FCR as $80-95 \%$ of families prefer teaching and care discussions to occur at the bedside [30-33].

Almost one-half of pediatric hospital medicine groups now use FCR [34]. FCR is also regarded as an important component of medical education. Concern has been raised by medical students and residents, in response to the perception that families are uncomfortable and that FCR undermines the learners' credibility [35-37]. However, FCR may actually enhance learners' credibility with families, and experienced residents cite benefits of communication and teamwork [35, 38-40]. Sir William Osler, distinguished physician and educator, noted in 1903 that "it is a safe rule to have no teaching without a patient for a text, and the best teaching is that taught by the patient himself', [41].

Some hospital systems also incorporate families at different levels of clinical care and education on a formal, systematic basis. Specific examples include family advisory boards and family/peer support groups, family presentations on care experiences at Grand Rounds, and hiring family members as consulting staff to specific programs. Hospitals that incorporate experienced family leaders as peer consultants or staff generally have already existing successful family advisory boards or peer support groups.

\section{The Ambulatory Setting}

In contrast to the inpatient setting, ambulatory encounters have no accepted, well-developed intervention such as 
bedside rounds in the inpatient setting. Accordingly, the inpatient setting tends to lead development of FCC initiatives $[42,43]$. However, FCC is recognized as the standard of care in all ambulatory settings, including primary care [44], specialty care [7], emergency care [45], and chronic care [46]. This recognition has led to much discussion about FCC, but fewer concrete initiatives, particularly when compared to the inpatient setting.

Operationalizing FCC in the ambulatory setting revolves around the Medical Home concept, which specifies that care for all children should be accessible, coordinated, comprehensive, family-centered, culturally competent, continuous, and compassionate [14]. The roots of the Medical Home lie in improving care for CSHCN [27], which may explain why so many tenets appear to focus on the child with special needs. However, FCC principles in the ambulatory setting are often described in terms of individual encounters. The MCHB conceptualizes FCC through 6 specific provider actions: (1) whether the health providers spent enough time, (2) listened carefully, (3) were sensitive to family values and customs, (4) provided specific information when needed, (5) made the parent feel like a partner in care, and (6) provided a language interpreter, if needed [47]. These concepts directly refer to the FCC principles of Information Sharing, Respect/ Honoring Differences, Partnership, and Care in Context of Family and Community, although Negotiation is not directly referenced.

Recommended FCC practices in the emergency room address patient flow, assuring family presence, providing care coordination, and improving communication [45]. Specific actions or training that operationalize these principles are less well-described; a blueprint that led to negotiation in a situation like our sample case report, Adam and his family, is not part of the recommended FCC practices.

Also less described is how FCC principles translate into optimal longitudinal care [14, 44]. The simple act of maintaining continuity of care, highly valued by families [48], is associated with optimal ambulatory care outcomes [49-51] and may serve as the foundation of longitudinal family-centered care. Family roles and needs evolve during a relationship, particularly in chronic care as the family becomes increasingly educated about a condition [52]. Over time, family trust of the provider may wax and wane [53], but little guidance exists to consistently improve and practice trust, partnership, and FCC.

Other FCC ambulatory practices are directed towards non-encounter, primary care-based services that address identified family needs. Examples include care coordination with subspecialists and community-based services [54, 55], family education and assistance [56, 57], and the use of parent advisers in quality improvement initiatives [58]. Similar practices have been reported in subspecialty fields, such as child development and rehabilitation medicine [7]. Grass-roots, family-led groups such as Family Voices and the Institute for Patient- and Family-Centered Care (formerly the Institute for Family-Centered Care) have developed several ambulatory initiatives. The Family-to-Family Health Information Centers, initiated by Family Voices and funded by the MCHB, provide education and resources to families and providers of CSHCN. Education and resources are achieved through one-on-one counseling, conferences, and direct training seminars [59].

Evidence suggests, however, that family needs are frequently not met in the ambulatory setting. In primary care, many families report not discussing desired topics on development and behavior [60-62]. Families of children with chronic or complex conditions report multiple unmet needs on information and physician collaboration $[9,10]$, specifically on community services, condition understanding, and networking [63, 64]. Families and physicians often have different expectations about how families can best be assisted [63]. Cultural differences may account for additional variation, particularly from immigrant families with different medical experiences $[65,66]$.

\section{Does Family-Centered Care Help? Current Evidence}

While seemingly intuitive that addressing family needs improves health care and outcomes, the evidence to support this is surprisingly scant. High quality evidence is necessary to drive changes in the health care system and policies that facilitate the practices that have been presented.

Studies examining family roles and levels of involvement within health care found that the strongest evidence for efficacy of FCC is in efficient use of resources and supporting health/mental health/well-being, and to a lesser extent in transition and cost containment [67, 68]. Limitations include a paucity of studies that isolated familycenteredness within a broader study, the lack of clarity of how FCC is operationalized, and most importantly, the absence of studies that include all the principles of FCC.

On the inpatient side, families specify that rounds are better when a nurse is present, when the family is introduced and involved in the discussion, and when medical terminology is avoided or interpreted [22, 28, 30, 31, 33, 35, 69]. Despite the scarcity of accepted FCR measures, studies report that FCR may increase family understanding and sharing in decision-making, and their sense of respect from the medical team $[22,35,38,69,70]$. FCR may increase providers' sense of teamwork, and from $45-90 \%$ of the time, generate new, previously unknown information from the family $[22,35,38,69,70]$.

Additional reviews suggest benefits from family-centered interventions. Patient-focused interventions support 
health literacy and self-management [71], and consumer involvement results in relevant information gain [72]. One review found that patient-centered care may lead to empowerment and improved self-management [5]. Two additional studies found that such an approach may translate into improved child health and behavior [73, 74].

\section{What Are the Barriers to Family-Centered Care?}

We feel that there are 3 main barriers to FCC: (1) understanding of FCC, (2) support for practices, and (3) highquality research that can guide hospitals, health systems, and policy makers.

\section{Understanding Family-Centered Care}

Ambiguity remains on what specific actions constitute FCC, on both the level of provider and patient. Some providers consider FCC as delegating more responsibility to families for care and decision making than families desire $[9,10]$. The MCHB construct of FCC does not offer a blueprint for practical provider action. In addition, focusing on encounter-based provider behavior does not always address the context of the community and the system of care.

Families do express a desire for partnership and joint decision-making and not necessarily increased responsibility and autonomy [75]. However, families also may not understand what they can and should expect in a partnership. Parents consistently rate high levels of satisfaction with a sense of partnership in a variety of child health care settings [76-78], even as subjective descriptions of care are far less satisfactory $[9,10]$. This discrepancy may reflect a ceiling effect of expectations; many parents may not know they can expect care, information, and decision-making on shared terms. Racial/ethnic differences and language disparities within FCC [66] suggest additional communication barriers that impede partnership building.

\section{Support for Practices}

Barriers to substantive partnering include inadequate or changing insurance coverage, and family financial difficulties and employment constraints [79]. These barriers erode continuity of care that comprises the base of FCC. Considerable time and repeated visits with providers may be needed to build family support and partnering [68, 80 , 81]. Reimbursement policies do not adequately support physician time and effort required to develop partnerships [80, 82, 83] putting motivated practitioners at risk for diminished reimbursement.

\section{Research}

Research is hampered by a lack of true validated measures and outcome measures for FCC. The lack of adequate research has been noted previously [84]. Measures that assess family impressions of care fall short in correlating specific actions with overall health and outcomes. The Measure of Processes of Care, a scale developed in the 1990s that evaluates the family-centeredness of services, has been largely used only for children with neurodevelopment conditions [85]. An index of family-centeredness based on the Consumer Assessment of Healthcare Providers and Systems survey has been used in national surveys [86, 87]. The AAP and Family Voices recently developed a FCC index modeled after the Medical Home Index to be used in practice assessment [88]. This tool asks providers to reflect on the family centeredness of care and ways to improve that care [89]. Outcome studies on FCC need to demonstrate that improvements resulting from FCC are not confused with other, concomitant-occurring nonFCC improvement initiatives.

\section{Moving Forward}

The advance of inpatient care demonstrates that transformation to a fully family-centered system of care can begin with small changes. However, system-level changes must occur to enable providers and families to engage in information-sharing and decision-making, creating the partnership that leads to improved outcomes. We recommend:

1. The principles of FCC should be acknowledged and actively incorporated within all clinical care delivery and practice guidelines. Where evidence exists, recognized FCC care practices should be followed. Where no evidence exists, particularly in the ambulatory setting, families and providers should lead and champion care delivery redesign that considers the needs of families [7]. Examples include shared decision making, trained language interpreter services, open scheduling, and families as partners in policy-making and facility redesign.

2. FCC principles are best learned through daily exposure and practice. Language should be respectful, care plans should be made jointly, and clinical decisions should consider the context of the family and community. These recommendations particularly apply to educators. As the current generation of trainees is taught the principles of FCC, learns the skills and ethics required, and experiences the benefits, the system will be more quickly impacted as this generation moves into practice and positions of leadership. 
3. Specific FCC practices, such as family presence at bedside rounds or procedures, should be implemented and evaluated as part of quality improvement projects. Such practices should be linked with measurable, controlled outcomes.

4. Measurement and evaluation tools for FCC should be developed and validated. The tools should have high enough standards that are linked to positive health outcomes and not only to parent satisfaction. Appropriate process measures may include family input, provider name recognition by families, and reduction of unmet needs. Research should examine expectations for long-term health care savings, contributions to society, improvements in health and quality of life, and patient satisfaction. All may be acceptable in lieu of short-term cost neutrality or savings.

5. Institutions should be familiar with all FCC principles and integrate families in high-level planning and design before the FCC label is applied to any health care initiative or process. FCC is a continuum of provider partnership and behavior. Accordingly, we cannot at this time recommend a threshold for when the FCC label is used by governing bodies or public relations.

6. Increases in external resources for care reform and system changes, specifically targeting FCC, should be offered. Ongoing education of legislators, policymakers, and funding agencies should raise awareness of the short- and long-term value of FCC as the standard for clinical care and within health care systems. Providers can team with family advocacy groups to advance the importance of FCC education and research.

7. Payment and reimbursement policies should recognize the time necessary to engage in FCC. Examples include the time needed for information sharing through counseling in-person or on the phone, care coordination, and other areas of family support. The upfront costs of reimbursing FCC practices may lead to more efficient and streamlined health care use overall for individual practices, hospitals, and health care systems.

It is our intent that this paper represents the beginning of a focused discussion, increased awareness, and support for FCC initiatives across the pediatric health spectrum.

\footnotetext{
Acknowledgments We thank Michael Cabana, MD, MPH, and Cynthia Minkovitz, MD, MPP, and the Academic Pediatric Association Health Care Delivery Committee for their insights and contributions towards forming the working group of authors. We thank Merle McPherson, MD, MPH, for her critical review and insights. The first author is supported by a grant from the Arkansas Biosciences Institute and grant KL2RR029883 from the National Center for Research Resources. The second author is supported by NIH/NICHD grant RMSTP K12 2K12H001097-11. The authors have no financial relationships to disclose.
}

Open Access This article is distributed under the terms of the Creative Commons Attribution Noncommercial License which permits any noncommercial use, distribution, and reproduction in any medium, provided the original author(s) and source are credited.

\section{References}

1. Institute of Medicine. (2001). Crossing the Quality Chasm: A New Health System for the 21st Century. Washington, DC: The National Academies Press; 2001. Available at http://www. iom.edu/ /media/Files/Report\%20Files/2001/Crossing-theQuality-Chasm/Quality\%20Chasm\%202001\%20\%20report\%20 brief.pdf. Accessed 6 Jan 2011.

2. American Academy of Pediatrics Committee on Hospital Care. (2003). Family-centered care and the pediatrician's role. Pediatrics, 112, 691-697.

3. Stange, K. C., Nutting, P. A., Miller, W. L., Jaen, C. R., Crabtree, B. F., Flocke, S. A., et al. (2010). Defining and measuring the patient-centered medical home. Journal of General Internal Medicine, 25(6), 601-612.

4. US Department of Human Services. Healthy People 2020. http:// www.healthypeople.gov/hp2020/Objectives/TopicArea.aspx? $\mathrm{id}=32 \&$ TopicArea $=$ Maternal $\% 2 \mathrm{c}+$ Infant + and + Child + Health. Accessed 6 Jan 2011.

5. Wagner, E. H., Bennett, S. M., Austin, B. T., Greene, S. M., Schaefer, J. K., \& Vonkorff, M. (2005). Finding common ground: Patient-centeredness and evidence-based chronic illness care. Journal of Alternate Complement Medicine, 11(1), S7-S15.

6. Antonelli, R. C., McAllister, J. W., \& Popp, J. (2009). Making care coordination a critical component of the pediatric health system: A multidisciplinary framework. New York: The Commonwealth Fund.

7. Bamm, E. L., \& Rosenbaum, P. (2008). Family-centered theory: Origins, development, barriers, and supports to implementation in rehabilitation medicine. Archives of Physical Medicine and Rehabilitation, 89(8), 1618-1624.

8. Shelton, T. L. (1999). Family-centered care in pediatric practice: When and how? Journal of Developmental and Behavioral Pediatrics, 20(2), 117-119.

9. MacKean, G. L., Thurston, W. E., \& Scott, C. M. (2005). Bridging the divide between families and health professionals' perspectives on family-centred care. Health Expectations, 8(1), 74-85.

10. Leiter, V. (2004). Dilemmas in sharing care: Maternal provision of professionally driven therapy for children with disabilities. Social Science and Medicine, 58(4), 837-849.

11. Jolley, J., \& Shields, L. (2009). The evolution of family-centered care. Journal of Pediatric Nursing, 24(2), 164-170.

12. Maternal and Child Health Bureau. Definition of Family-Centered Care: www.familyvoices.org/admin/work_family_centered/ files/FCCare.pdf. 2005. Accessed Jan 62011.

13. Institute for Patient- and Family-Centered Care. Patient- and Family-Centered Care Core Concepts. http://www.ipfcc.org/ faq.html. Accessed 6 Jan 2011.

14. American Academy of Pediatrics. (2002) The medical home 2002. Pediatrics, 110, 184-186.

15. Maternal and Child Health Bureau. Achieving and measuring success: A national agenda for children with special health care needs. www.mchb.hrsa.gov/programs/specialneeds/measuresuccess.htm. Accessed 18 Jan 2011.

16. Joint Principles of the Patient Centered Medical Home: American Academy of Family Physicians, American Academy of 
Pediatrics, American College of Physicians, American Osteopathic Association. 2007.

17. Epstein, R. M., Fiscella, K., Lesser, C. S.,\& Stange, K. C. (2010). Why the nation needs a policy push on patient-centered health care. Health Affairs (Millwood), 29(8), 1489-1495.

18. Shields, L., Pratt, J., \& Hunter, J. (2006). Family centred care: A review of qualitative studies. Journal of Clinical Nursing, 15(10), $1317-1323$

19. L'Hopital Des Enfants-Malades. (1981). The world's first children's hospital, founded in Paris in 1802. Pediatrics, 67(5), 670.

20. Samuel Gridley Howe and the education of the retarded. (1976). Hospital Community Psychiatry, 27(7), 478-479.

21. Linfors, E. W., \& Neelon, F. A. (1980). Sounding Boards. The case of bedside rounds. New England Journal of Medicine, 303(21), 1230-1233.

22. Cameron, M. A., Schleien, C. L., \& Morris, M. C. (2009). Parental presence on pediatric intensive care unit rounds. Journal of Pediatrics, 155(4), 522-528.

23. Bergman, A. I., \& Singer, G. H. (1996). The thinking behind new public policy. In G. H. S. Singer, L. E. Powers, A. L. Olsen (Ed.), Redefining family support: Innovations in public-private partnerships. Baltimore, MD: Brookes Publishing.

24. Johnson, B. H. (2000). Family-centered care: Four decades of progress. Families, Systems \& Health, 18, 137-156.

25. Children with Special Health Care Needs. (1987). Campaign '87. Surgeon General's Report. Commitment to: Family-Centered, Community-Based, Coordinated Care. Viewpoints. Rockville, MD: US Department of Health and Human Services; June 1987.

26. Patient Protection and Accountable Care Act, Public Law 111-148 (2010). Available at http://thomas.loc.gov/cgi-bin/ bdquery/z?d111:HR03590:@@@\&summ2=m\&summary. Accessed 6 Jan 2011.

27. Sia, C., Tonniges, T. F., Osterhus, E., \& Taba, S. (2004). History of the medical home concept. Pediatrics, 113(5), 1473-1478.

28. Muething, S. E., Kotagal, U. R., Schoettker, P. J., Gonzalez del Rey, J., \& DeWitt, T. G. (2007). Family-centered bedside rounds: A new approach to patient care and teaching. Pediatrics, 119(4), 829-832.

29. Sisterhen, L. L., Blaszak, R. T., Woods, M. B., \& Smith, C. E. (2007). Defining family-centered rounds. Teaching and Learning in Medicine, 19(3), 319-322.

30. Romano, J. (1941). Patients' attitudes and behavior in ward round teaching. JAMA, 117, 664-667.

31. Lewis, C., Knopf, D., Chastain-Lorber, K., Ablin, A., Zoger, S., Matthay, K., et al. (1988). Patient, parent, and physician perspectives on pediatric oncology rounds. Journal of Pediatrics, 112(3), 378-384.

32. Simons, R. J., Baily, R. G., Zelis, R., \& Zwillich, C. W. (1989). The physiologic and psychological effects of the bedside presentation. New England Journal of Medicine, 321(18), 1273-1275.

33. Lehmann, L. S., Brancati, F. L., Chen, M. C., Roter, D., \& Dobs, A. S. (1997). The effect of bedside case presentations on patients' perceptions of their medical care. New England Journal of Medicine, 336(16), 1150-1155.

34. Mittal, V. S., Sigrest, T., Ottolini, M. C., et al. (2010). Familycentered rounds on pediatric wards: A PRIS Network survey of US and Canadian Hospitalists. Pediatrics, 126, 37-43.

35. Landry, M. A., Lafrenaye, S., Roy, M. C., \& Cyr, C. (2007). A randomized, controlled trial of bedside versus conference-room case presentation in a pediatric intensive care unit. Pediatrics, 120(2), 275-280.

36. Nair, B. R., Coughlan, J. L., \& Hensley, M. J. (1997). Student and patient perspectives on bedside teaching. Medical Education, 31(5), 341-346.
37. Wang-Cheng, R. M., Barnas, G. P., Sigmann, P., Riendl, P. A., \& Young, M. J. (1989). Bedside case presentations: Why patients like them but learners don't. Journal of General Internal Medicine, 4(4), 284-287.

38. Aronson, P. L., Yau, J., Helfaer, M. A., \& Morrison, W. (2009). Impact of family presence during pediatric intensive care unit rounds on the family and medical team. Pediatrics, 124(4), $1119-1125$

39. Rogers, H. D., Carline, J. D., \& Paauw, D. S. (2003). Examination room presentations in general internal medicine clinic: Patients' and students' perceptions. Academic Medicine, 78(9), 945-949.

40. Gonzalo, J. D., Masters, P. A., Simons, R. J., \& Chuang, C. H. (2009). Attending rounds and bedside case presentations: Medical student and medicine resident experiences and attitudes. Teaching and Learning in Medicine, 21(2), 105-110.

41. Osler, W. (1903). On the need of a radical reform in our methods of teaching senior students. Medical News, 82, 49-53.

42. Hobbs, S. E., \& Sodomka, P. F. (2000). Developing partnerships among patients, families, and staff at the Medical College of Georgia Hospital and Clinics. Joint Commission Journal on Quality Improvement, 26(5), 268-276.

43. Landis, M. (2007). The many roles of families in "family-centered care"-part IV. Pediatrics Nursing, 33(3), 263-265.

44. Hagan, J. F., Shaw, J. S., \& Duncan, P. (Eds.). (2008). Bright futures: Guidelines for health supervision of infants, children, and adolescents (3rd ed.). Elk Grove Village, IL: American Academy of Pediarics.

45. O’Malley, P. J., Brown, K., \& Krug, S. E. (2008). Patient- and family-centered care of children in the emergency department. Pediatrics, 122(2), e511-e521.

46. American Academy of Pediatrics and the National Center for Medical Home Implementation. Care Partnership Support. www.medicalhomeinfo.org/how/care_partnership_support.aspx. Accessed 6 Jan 2011.

47. US Department of Health and Human Services, Health Resources and Service Administration, Maternal and Child Health Bureau. The National Survey of Children with Special Health Care Needs Chartbook 2005-2006. Rockville, MD; US Department of Health and Human Services, 2007.

48. O'Malley, A. S. (2004). Current evidence on the impact of continuity of care. Current Opinion in Pediatrics, 16(6), 693-699.

49. Christakis, D. A., Feudtner, C., Pihoker, C., \& Connell, F. A. (2001). Continuity and quality of care for children with diabetes who are covered by medicaid. Ambulatory Pediatrics, 1(2), 99-103.

50. Christakis, D. A., Wright, J. A., Zimmerman, F. J., Bassett, A. L., \& Connell, F. A. (2003). Continuity of care is associated with well-coordinated care. Ambulatory Pediatrics, 3(2), 82-86.

51. Brousseau, D. C., Meurer, J. R., Isenberg, M. L., Kuhn, E. M., \& Gorelick, M. H. (2004). Association between infant continuity of care and pediatric emergency department utilization. Pediatrics, 113(4), 738-741.

52. Feldman, H. M., Ploof, D., \& Cohen, W. I. (1999). Physicianfamily partnerships: The adaptive practice model. Journal of Developmental and Behavioral Pediatrics, 20(2), 111-116.

53. Hall, M. A., Camacho, F., Dugan, E., \& Balkrishnan, R. (2002). Trust in the medical profession: Conceptual and measurement issues. Health Services Research, 37(5), 1419-1439.

54. Care coordination in the medical home. (2005). Integrating health and related systems of care for children with special health care needs. Pediatrics, 116(5), 1238-1244.

55. McAllister, J. W., Presler, E., \& Cooley, W. C. (2007). Practicebased care coordination: A medical home essential. Pediatrics, 120(3), e 723-e733. 
56. Minkovitz, C. S., Hughart, N., Strobino, D., Scharfstein, D., Grason, H., Hou, W., et al. (2003). A practice-based intervention to enhance quality of care in the first 3 years of life: The healthy steps for young children program. JAMA, 290(23), 3081-3091.

57. Johnston, B. D., Huebner, C. E., Tyll, L. T., Barlow, W. E., \& Thompson, R. S. (2004). Expanding developmental and behavioral services for newborns in primary care; Effects on parental well-being, practice, and satisfaction. American Journal of Preventive Medicine, 26(4), 356-366.

58. Spread of the Medical Home Concept. (2006). Cambridge, MA: National Initiative for Children's Healthcare Quality.

59. Families helping families of children and youth with special health care needs \& professionals who serve them: Family Voices; January 2007.

60. Olson, L. M., Inkelas, M., Halfon, N., Schuster, M. A., O'Connor, K. G., \& Mistry, R. (2004). Overview of the content of health supervision for young children: Reports from parents and pediatricians. Pediatrics, 113(6), 1907-1916.

61. Schuster, M. A., Duan, N., Regalado, M., \& Klein, D. J. (2000). Anticipatory guidance: What information do parents receive? What information do they want? Archives of Pediatrics and Adolescent Medicine, 154(12), 1191-1198.

62. Houtrow, A. J., Kim, S. E., Chen, A. Y., \& Newacheck, P. W. (2007). Preventive health care for children with and without special health care needs. Pediatrics, 119(4), e821-e828.

63. Liptak, G. S., \& Revell, G. M. (1989). Community physician's role in case management of children with chronic illnesses. Pediatrics, 84(3), 465-471.

64. Liptak, G. S., Orlando, M., Yingling, J. T., Theurer-Kaufman, K. L., Malay, D. P., Tompkins, L. A., et al. (2006). Satisfaction with primary health care received by families of children with developmental disabilities. Journal of Pediatrics Health Care, 20(4), 245-252.

65. Goode, T. D., Haywood, S. H., Wells, N., \& Rhee, K. (2009). Family-centered, culturally, and linguistically competent care: Essential components of the medical home. Pediatric Annals, 38(9), 505-512.

66. Coker, T. R., Rodriguez, M. A., \& Flores, G. (2010). Familycentered care for US children with special health care needs: Who gets it and why? Pediatrics, 125(6), 1159-1167.

67. Kuhlthau, K., Bloom, S., Van Cleave, J., Romm, D., Klatka, K., Homer, C., et al. Evidence for family centered care for children with special health care needs: A systematic review. Academic Pediatrics 2011; in press.

68. Kuo, D. Z., Bird, T. M., \& Tilford, J. M. (2010). Associations of family-centered care with health care outcomes for children with special health care needs. Maternal Child Health Journal. (epub 2010 July 17).

69. Latta, L. C., Dick, R., Parry, C., \& Tamura, G. S. (2008). Parental responses to involvement in rounds on a pediatric inpatient unit at a teaching hospital: A qualitative study. Academic Medicine, 83(3), 292-297.

70. Rosen, P., Stenger, E., Bochkoris, M., Hannon, M. J., \& Kwoh, C. K. (2009). Family-centered multidisciplinary rounds enhance the team approach in pediatrics. Pediatrics, 123(4), e603-e608.

71. Coulter, A., \& Ellins, J. (2007). Effectiveness of strategies for informing, educating, and involving patients. BMJ, 335(7609), 24-27.

72. Nilsen, E. S., Myrhaug, H. T., Johansen, M., Oliver, S., \& Oxman, A. D. (2006). Methods of consumer involvement in developing healthcare policy and research, clinical practice guidelines and patient information material. Cochrane Database System Review, 3: CD004563.
73. Dunst, C. J., \& Trivette, C. M. (2009). Meta-analytic structural equation modeling of the influences of family-centered care on parent and child psychological health. International Journal of Pediatrics. (epub 2009 Nov 30).

74. Dunst, C. J., Trivette, C. M., \& Hamby, D. W. (2007). Metaanalysis of family-centered helpgiving practices research. Ment Retard Dev Disabil Res Rev, 13(4), 370-378.

75. Arango, P. (1999). A parent's perspective on family-centered care. Journal of Developmental and Behavioral Pediatrics, 20(2), 123-124.

76. Denboba, D., McPherson, M. G., Kenney, M. K., Strickland, B., \& Newacheck, P. W. (2006). Achieving family and provider partnerships for children with special health care needs. Pediatrics, 118(4), 1607-1615.

77. Knapp, C. A., Madden, V. L., \& Marcu, M. I. (2009). Factors that affect parent perceptions of provider-family partnership for children with special health care needs. Maternal Child Health Journal. (epub 2009 July 31 ).

78. Halfon, N., Inkelas, M., Mistry, R., \& Olson, L. M. (2004). Satisfaction with health care for young children. Pediatrics, 113(6), 1965-1972.

79. Wells, N., Krauss, M. W., Anderson, B., Gulley, S., Leiter, V., O'Neil, M., et al. (2000). What do families say about health care for children with special health care needs? Your voice counts!! The Family Partners Project report to families. Boston, MA: Family Voices at the Federation for Children with Special Health Care Needs.

80. Antonelli, R. C., \& Antonelli, D. M. (2004). Providing a medical home: The cost of care coordination services in a communitybased, general pediatric practice. Pediatrics, 113(5), 1522-1528.

81. Antonelli, R. C., Stille, C. J., \& Antonelli, D. M. (2008). Care coordination for children and youth with special health care needs: A descriptive, multisite study of activities, personnel costs, and outcomes. Pediatrics, 122(1), e209-e216.

82. Bodenheimer, T. (2006). Primary care-will it survive? New England Journal of Medicine, 355(9), 861-864.

83. McAllister, J. W., Sherrieb, K., \& Cooley, W. C. (2009). Improvement in the family-centered medical home enhances outcomes for children and youth with special healthcare needs. Journal of Ambulatory Care Management, 32(3), 188-196.

84. Shields, L., Pratt, J., Davis, L. M., \& Hunter, J. (2007). Familycentred care for children in hospital. Cochrane Database System Review, (1):CD004811.

85. King, G. A., Rosenbaum, P. L., \& King, S. M. (1997). Evaluating family-centred service using a measure of parents' perceptions. Child: Care, Health and Development, 23(1), 47-62.

86. Bethell, C., Reuland, C. H., Halfon, N., \& Schor, E. L. (2004). Measuring the quality of preventive and developmental services for young children: National estimates and patterns of clinicians' performance. Pediatrics, 113(6), 1973-1983.

87. Brousseau, D. C., Hoffmann, R. G., Nattinger, A. B., Flores, G., Zhang, Y., \& Gorelick, M. (2007). Quality of primary care and subsequent pediatric emergency department utilization. Pediatrics, 119(6), 1131-1138.

88. Cooley, W. C., McAllister, J. W., Sherrieb, K., \& Clark, R. E. (2003). The Medical Home Index: Development and validation of a new practice-level measure of implementation of the Medical Home model. Ambulatory Pediatrics, 3(4), 173-180.

89. Family Voices. (2008). Family-Centered Care Self-Assessment Tool 2008. www.familyvoices.org/resources/tools. Accessed 18 Jan 2011

90. Shaller, D. (2007). Patient-centered care: What does it take? Shaller Consulting. 